\title{
Analysis of Fossil Pollen Record from the Late Holocene in the Turkish Highland (Middle Taurus,Turkey)
}

\author{
İpek Özalp ${ }^{1 *}$, Hülya Caner ${ }^{2}$, Nurgül Karlıoğlu Kılıç Meral Avcı ${ }^{4}$, \\ ${ }^{1}$ Geography Department, Namık Kemal University, Tekirdağ. \\ ${ }^{2}$ Institute of Marine Sciences and Management, Istanbul University, Istanbul. \\ ${ }^{3}$ Department of Forest Botany, Faculty of Forestry, Istanbul University, Istanbul. \\ ${ }^{4}$ Geography Department, Istanbul University, Istanbul. \\ e-mail: ipek.ozalp@istambul.edu.tr
}

Received: 22 April 2017/Accepted: 02 June 2017

\begin{abstract}
In this study, we have investigated changes of vegetation in the Mediterranean Region of Turkey approximately for the last 5000 years using pollen analysis. There were some differences in the past vegetation, but principally vegetation structure has shown similarity with the modern one. Main difference appeared with the existence of Betula.
\end{abstract}

Keywords: Mediterranean region, arboreal-nonarboreal pollen, soil samples, radiocarbon dating, human impact on vegetation

\section{Introduction}

Fossil pollen studies are important to detect vegetation changes caused by climatic or anthropogenic reasons. Our study area is located in the Eastern Mediterranean Region and it has special place in terms of longstanding human impact on local vegetation (Karlıoğlu et al. 2015; Vermoere et al. 2002; Waelkens et al. 1999; Woldring 1984; Zeist Van et al. 1975; Zeist Van \& Bottema 1991). Most of these studies were conducted in this place to emphasize similar outcome, because of this situation we made this research to encounter arboriculture zone and reveal vegetation history.

\section{Material and methods}

A soil profile that was assessed in this study is located in the Turkish highland area (1550 meter high), known as Middle Taurus in the Mediterranean region (Fig. 1). In the study area there is no a lake suitable for tracing vegeta- tion history based on fossil pollen in lake deposits, so we worked with soil profile series. The profile was 2,4 meters long and samples were taken with $5 \mathrm{~cm}$ intervals. After standard procedure of maceration (Erdtman's acetolysis) (Erdtman 1954), slides were counted and pollen diagram was plotted by using $\mathrm{C} 2$ program. Two different levels of deposits from this profile (that contained organic carbon) were used for radiocarbon dating. Several levels did not contain enough pollen to obtain reliable results of counting so we included a second pollen slide to calculate percentages based on the sum of at least $250 \mathrm{AP}+\mathrm{NAP}$ (arboreal pollen + non-arboreal pollen). 


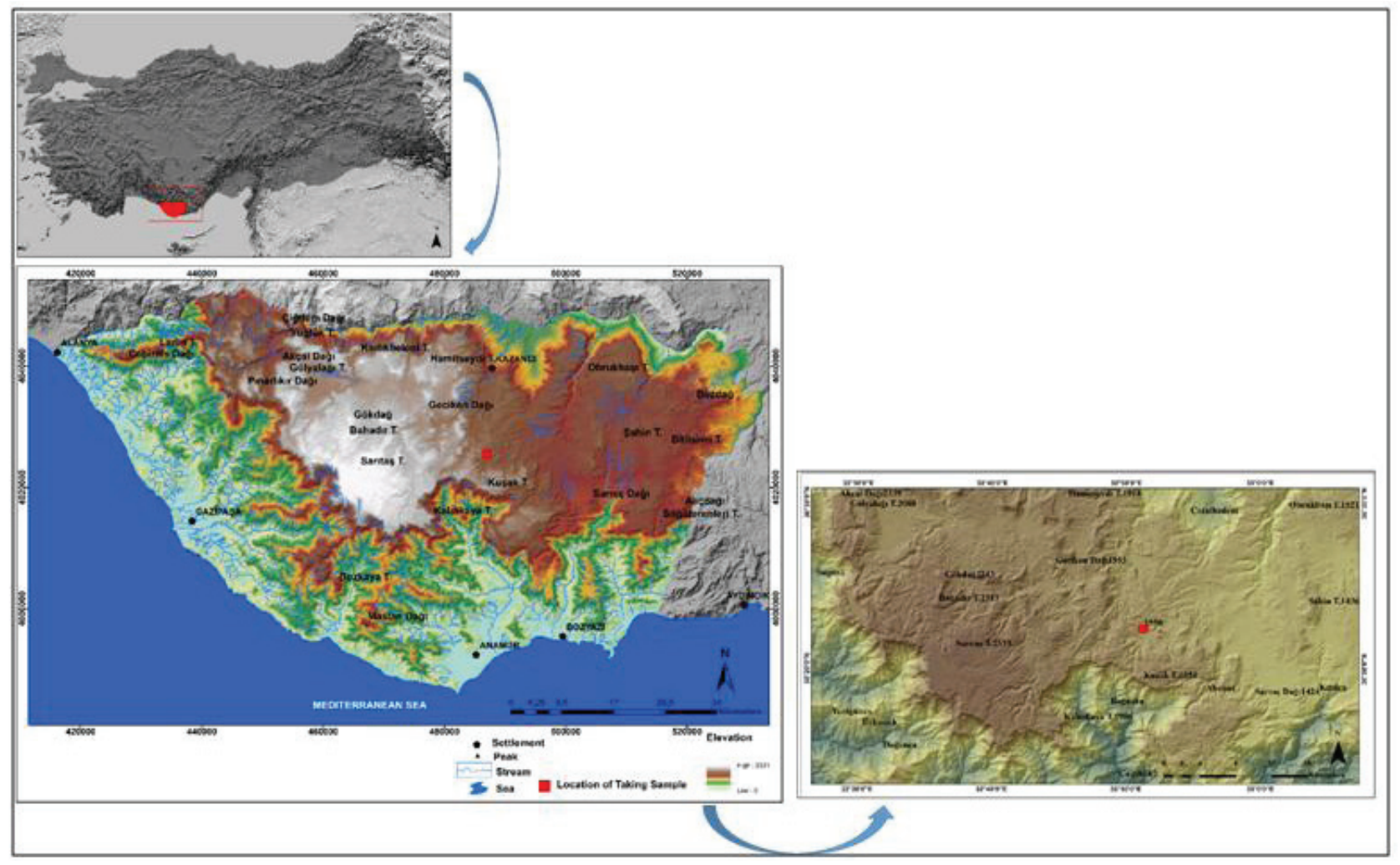

Figure 1. Location map of study area

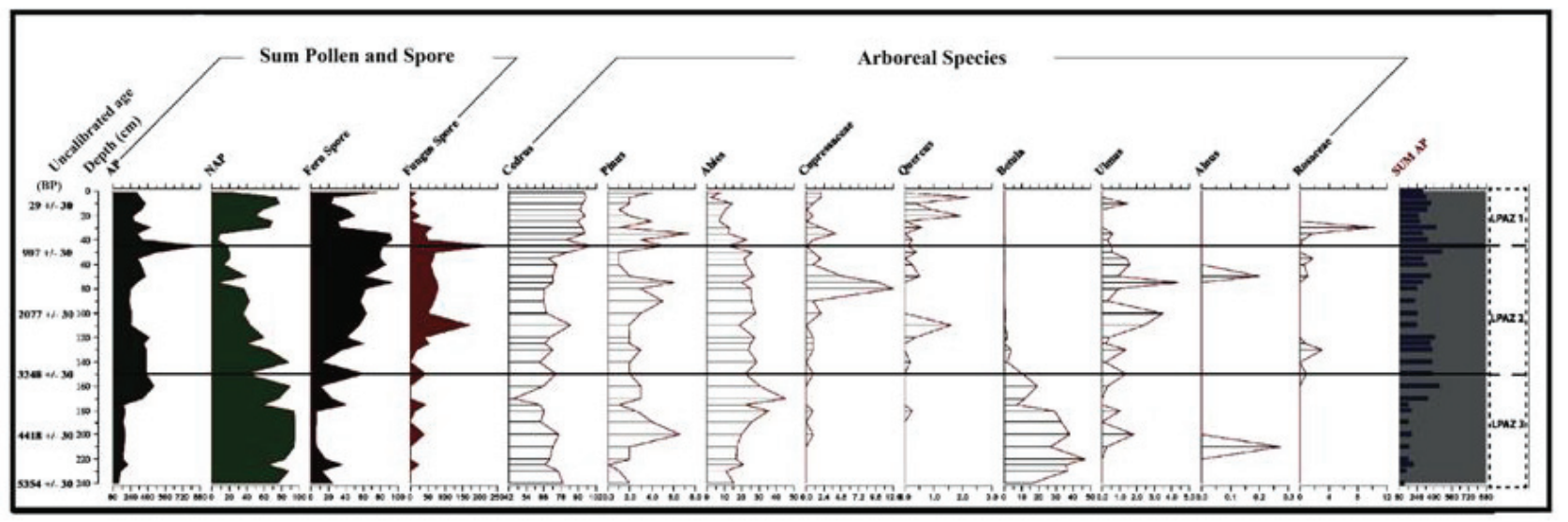

Figure 2. Pollen diagram of the arboreal plants

\section{Results}

Pollen diagram (Figs. 2-4) was divided into three local pollen assemblage zones (LPAZ 1, LPAZ 2, LPAZ 3).
Frequent arboreal pollen types are Cedrus, Abies, $P i$ nus, Quercus, Betula, Ulmus, Alnus and some pollen grains belong to Cupressaceae and Rosaceae family. Non-arboreal pollen grains, encountered in this study, are: Chenopodiaceae, Asteraceae, Polygonum, Caryophyllaceae, Araceae, 
Lamiaceae, Cannaceae, Liliaceae, Geraniaceae and Amaryllidaceae. Moreover, fungi spores and fern spores were counted (Figs. 2-4).

Most remarkable changes were observed for the last five thousand years. Cedrus is the most common tree throughout the pollen diagram. Abies is another dominant genus, but Pinus showed quite low rate through the pollen zones. The reason of increasing Cedrus pollen in the upper part of the diagram is probably related to afforestation. Some non-arboreal taxa such as Polygonum, Chenopodia- ceae, Caryophyllaceae and Asteraceae can be considered as indicator of human impact on vegetation, but in this study an increase in pollen percentages of these taxa was not synchronous with the decrease of arboreal taxa. That is why, this increase shouldn't be related to human influence on vegetation. Betula is absent in actual vegetation, but Betula pollen type was found relatively numerous in the samples of 220, 230 and $240 \mathrm{~cm}$ (Özalp 2016; Özalp et al. 2016; Avci 2004). The mentioned zones are also important with regard to highest rate of non-arboreal pollen grains.

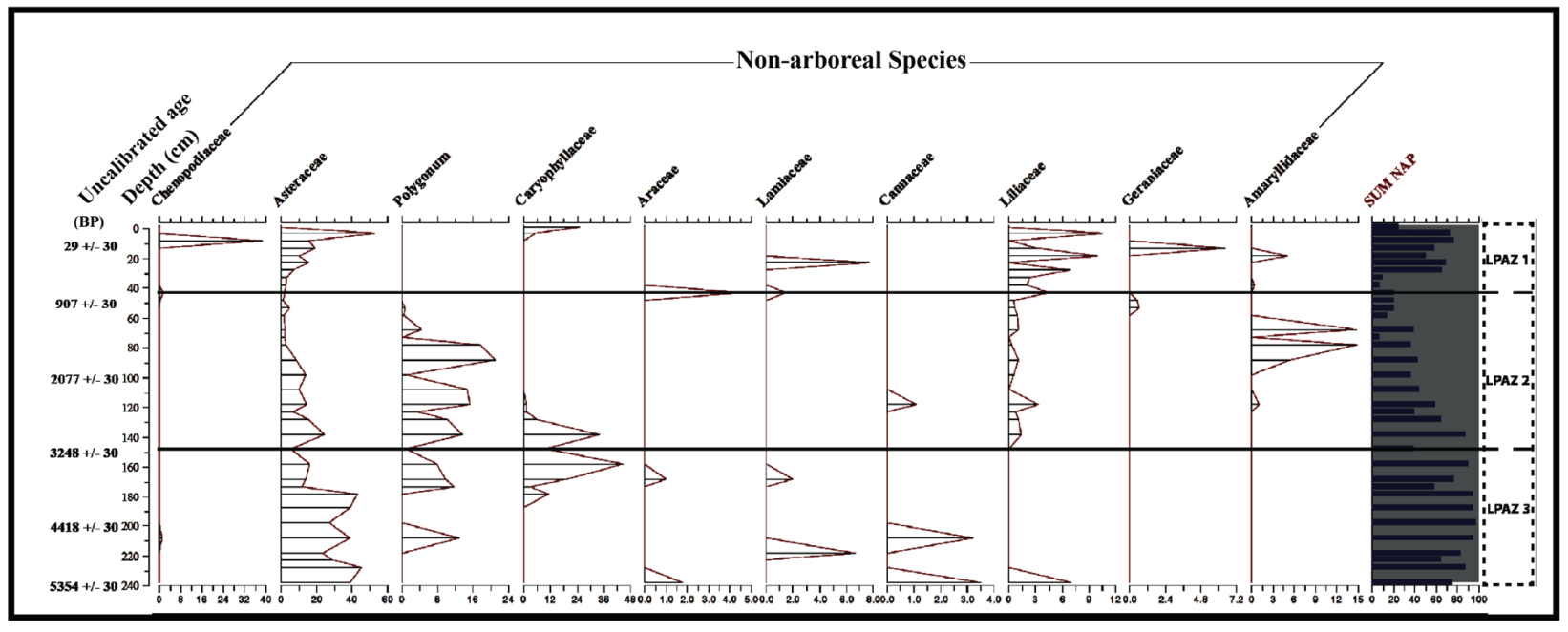

Figure 3. Pollen diagram of non-arboreal plants

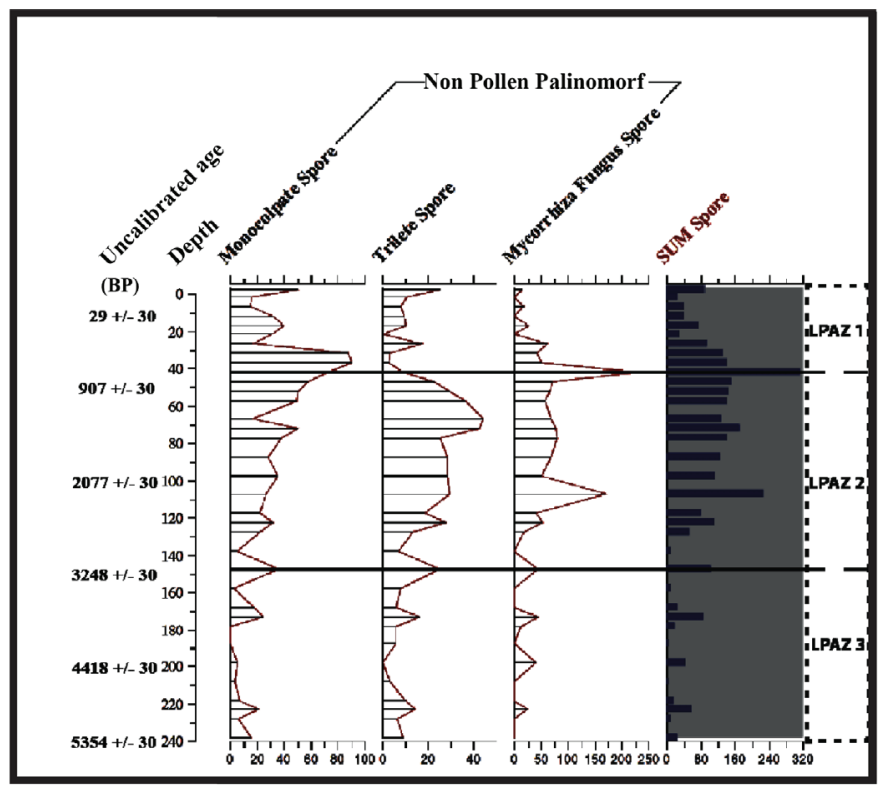

Figure 4. Diagram of non-pollen palinomorf 


\section{Conclusions}

As can be seen, dominant elements are arboreal species in the pollen diagram. Arboriculture species, that are frequently encountered in other studies, such as: Olive, Juglans, Fraxinus, and also secondary vegetation element, such as Juniperus are absent (Zeist et al. 1975). Non-arboreal anthropogenic taxa, such as: Polygonum, Chenopodiaceae, Caryophyllaceae, Asteraceae, Plantago, Cerealia type, are either absent or too insufficient to correlate them with particular phases of human impact. The only anthropogenic indicator can be increasing Cedrus pollen record in the upper part of the diagram. Presence of Betula pollen is most surprising and remarkable, because this could point out any climatic change.

\section{References}

Avci M., 2004, İç Anadolu Bölgesi Ormanlarının Son S1ğınakları, Karacadağ ve Karadağ Volkanlarının Bitki Örtüsü (in Turkish), Çantay Kitabevi, İstanbul: 33-34.

Bottema S. \& Woldring H., 1984, Late Quaternary vegetation and climate of southwestern Turkey II, Palaeohistoria $26: 123-149$.

Erdtman G., 1954, An Introduction to Pollen Analysis, Chronica Botanica, USA.

Karlığlu N., Caner H., Rauh N.K., Akkemik Ü., Köse N. \& Conor E.M., 2015, Palynological evidence for human occupation in western Rough Cilicia South West Turkey, Quaternary International 401: 109-122.
Özalp İ., 2016, Vegetation of the Akçalı Mountains and its Changes (in Turkish), (Unpublished PhD thesis) Istanbul University Institute of Social Sciences Department of Geography, İstanbul.

Özalp İ., Avci M., Caner H. \& Karlioğlu Kiliç N., 2016, Taşeli platosunda Türke yaylası (Anamur-Mersin) polen analizi sonuçlarının arboreal türler açısından değerlendirilmesi [Pollen analysis of Türke highland (Anamur-Mersin) at Taşeli plateau for arboreal species], TURQUA Türkiye Kuvaterner Sempozyumu 8-11 Mayıs 2016 İstanbul Teknik Üniversitesi, İstanbul: 105-105

Vermoere M., Bottema S., Vanhecke L., Waelkens M., 2002, Late Holocene human occupation in SW Turkey, palynological evidence from wetlands, The Holocene 12(5): 569-584.

Waelkens M., Paulissen E, Vermoere M., Degryse P., Celis D., Schroyen K., Cupere B., Librecht I., Nackaerts K., Vanhaverbeke H., Viaene W., Muchez P., Ottenburgs R., Deckers S., Neer V.W., Smets E., Govers G. \& Verstraeten G., 1999, Man and environment in The Territory of Sagalassos a classical city in SW Turkey, Quaternary Science Reviews 18: 697-709.

Zeist Van W., Woldring H. \& Stapert D., 1975, Late Quaternary vegetation and climate of southwestern Turkey, Palaeohistoria Acta et Communicationes Instituti BioArchaeologici Universitatis Groninganae: 53-143.

Zeist Van W. \& Bottema S., 1991, Late Quaternary vegetation of the Near East, Beihefte Zum Tübinger Atlas Des Vorderen Orients, Reihe A Nr. 18 Dr. Ludwig Reichert Verlag Wiesbaden: 73-89. 